\title{
Strategic Sourcing: Developing a Progressive Framework for Make-Or-Buy Decisions
}

\author{
Rubén Medina-Serrano iD, Reyes González-Ramírez iD, Jose Gasco-Gasco iD, Juan Llopis-Taverner iD \\ University of Alicante (Spain) \\ ruben.medina.serrano@googlemail.com,mr.gonzalez@ua.es,jl.gasco@ua.es,juan.llopis@ua.es
}

Received: February 2019

Accepted: November 2019

\begin{abstract}
:
Purpose: Make-or-buy decisions represent a critical dilemma faced by many firms. The appropriate decision between designing and manufacturing parts or services in-house, buying them from external providers or combining both is a fundamental firm process. This paper seeks to address this question by updating the traditional make-or-buy literature with new academic insights, developing a make-or-buy framework with a tool for its operationalisation to help managers evaluate sourcing decisions.
\end{abstract}

Design/methodology/approach: First, a literature review of the principal theories and approaches about make-or-buy decisions is discussed. Second, the development of the make-or-buy framework is described and explained based on the results of qualitative interviews with practitioners and a set of interviews of an in-firm case study. Third, the results and the implementation of the framework are outlined.

Findings: This study addresses the problematic identified by developing a practical framework to guide practitioners and academics to make sourcing decisions in a structured and standardized manner Our results suggest to build multidisciplinary teams of different disciplines (purchasers, Research and Develop employees $(\mathrm{R} \& \mathrm{D})$, quality representatives, etc.) in order to avoid resolving make-or-buy decisions under the conditions of inaccurate and incomplete information.

Implications: This paper aims to contribute to the study of the make-or-buy literature in supply chain management through the graphical representation of why and how make-or-buy decisions are made. Interestingly, the paper presents relevant dimensions and factors to be studied and evaluates possible outcomes when approaching make-or-buy decisions.

Originality/value: Our results suggest that practitioners should combine this framework with a pairwise comparison matrix and a multi-criteria decision analysis based on the TOPSIS methodology to assess strategic sourcing decisions.

Keywords: make-or-buy decisions, decision-making, outsourcing, plural sourcing, hybrid sourcing, literature review

\section{To cite this article:}

Medina-Serrano, R., González-Ramírez, R., Gasco-Gasco, J., \& Llopis-Taverner, J. (2020). Strategic sourcing: Developing a progressive framework for make-or-buy decisions. Journal of Industrial Engineering and Management, 13(1), 133-154. https://doi.org/10.3926/jiem.2858 


\section{Introduction}

The critical question practitioners face when making the decision between manufacturing their own products or buying them from external providers was studied in the past. However, it failed to consider hybrid and plural sourcing options with the combination of a practical tool for their operationalisation. Whereas hybrid sourcing refers to procurement of the entire volume from a single mode that exhibits mixed governance characteristics, plural sourcing refers to the combination of insourcing and outsourcing simultaneously (Jacobides \& Hitt, 2005; Park \& Ro, 2011; Parmigiani, 2007; Puranam, Gulati \& Bhattacharya, 2013). This mode of governance was not considered by many frameworks developed in the past like the one designed by Cánez, Platts and Probert (2000). Plural sourcing, also called "concurrent sourcing" or "make-and-buy" in the literature, is widely implemented by practitioners.

Additionally, to the historical and dichotomous make-or-buy perspective, decision makers should also take into account the hybrid and plural sourcing views, as well as the creation of strategic alliances. According to Doz, Prahalad and Hamel (1990), joint ventures provide low-cost, fast access to new markets by sharing risks and borrowing expertise from local partners.

Instability of the alliance or joint venture may be influenced by the acquisition of local knowledge by the foreign partner.

Managers and decision makers want to know which factors may influence a firm's decision to buy a part or service rather than manufacture it internally and how relevant factors should be evaluated in order to take the right decision and avoid future problems and extra costs. Whereas many make-or-buy decisions are instinctive, and firms continue to make decisions on a piecemeal basis (McIvor, 2013), firms have limited resources and cannot afford to have all engineering and manufacturing resources in-house. Hence, make-or-buy decisions and their consequences got more attention because of their influence on the firm's performance. Thus, an updated, efficient, comprehensive and practice-oriented framework to address make-or-buy decisions for either R\&D or manufacturing activities validated with a real case study was required. In contrast to the majority of past works, this study addresses not only economic but also strategic-related criteria in resolving make-or-buy decisions in a structured and efficient manner. The rest of the paper is organized as follows: Section 2 analyses the make-or-buy literature and develops a conceptual make-or-buy framework. In Section 3, a qualitative analysis of interviews with middle-level managers and an in-firm-case study are explained. In Section 4, the proposed framework is described and validated through the case study. Then, trends from experimental evaluations and analyses are presented in order to assess the effectiveness and efficiency of the proposed model in Section 5. Finally, the main conclusions and the topics related to this study are presented in Section 6.

\section{Literature Review}

\subsection{Previous Make-or-Buy Literature}

Previous make-or-buy literature has been researched in the past. For instance, Walker (1988) considered that activities should be insourced in order to avoid appropriation risks, technology diffusion and end-product degradation. In his view, the assessment of the strategic risk associated with the activity should be favourable to the organisation's competence in performing the activity as opposed to that of suppliers. While Venkatesan (1992) stated that manufacturing processes where external providers have a comparative advantage against the firm should be outsourced and core manufacturing processes should be insourced, Welch and Nayak (1992) argued that activities or services should be insourced whenever the process technology is mature and superior at the firm. Quinn and Hilmer (1994) supported the outsourcing decision when a high need for flexibility is required and insourcing when the need for flexibility is low. According to Apte and Mason (1995), it is necessary to form a strategic partnership with an external provider or invest to acquire the required competence whenever an activity has a high strategic importance and a low relative efficiency. McIvor, Humphreys and McAleer (1997) developed one employing criteria like core competences, capabilities and costs for evaluating make-or-buy decisions. They highlighted the importance of comparing internal and external criteria. On the other hand, Sislian and Satir (2000) developed a sourcing framework based on four factors which were subcategorised into (1) primary factors, namely: 
competitive advantage and demand flexibility, and (2) secondary factors, which were process capability, process maturity and strategic risks. The same year Cánez et al. (2000) developed a make-or-buy framework. Latterly, McIvor (2009) proposed a TCE-RBV combined theoretical framework and Brewer, Ashenbaum and Carter (2013) validated it and extended it with performance attributes. Recently, Brem and Elsner (2018) proposed a framework with two kinds of make-or-buy decisions: one associated with production and quality function and the other associated with research and development (R\&D).

\subsection{Make-or-Buy: Theoretical Approaches}

As has been done in the past by other researchers like Dibbern, Goles, Hirschheim and Jayatilaka (2004) with their theoretical foundations or Cánez et al. (2000) with their make-or-buy framework, we have summarised the main theories which may influence make-or-buy decisions. In addition to the theories categorised by Dibbern et al. (2004), we have identified theories and insights concerning alliances, hybrid sourcing, plural sourcing, transaction cost economics (TCE), resource-based view (RBV) theories and make-or-buy frameworks. Our review work began with the systematic identification of renowned academic journals in the field of make-or-buy decisions from the literature. A search for the keywords "make-or-buy" in the Proquest, Web of Science and Google Scholar academic databases was performed, following a database search methodology similar to the one adopted by Butkovic, Kauric, and Mikulic (2016). Articles and publications dealing with make-or-buy decisions were listed on a spreadsheet along with some detailed information about the year of publication, the author's name, the methodology employed and key points of the related article. Our electronic search was completed with a manual one, especially focused on tracing the papers cited in the bibliography of the previously selected articles. Articles fulfil the requirement of appearing in the databases mentioned above and were selected based on their journal impact and citation reputation. The interest of researchers and practitioners about the make-or-buy literature, and especially the literature favoring the "buy" decision, has increased over the last few decades. Make-or-buy decisions have been addressed from multiple viewpoints. Due to the increased relevance of resource theories in recent decades, we have extended the two strands identified by Cánez et al. (2000) to four approaches.

The first approach tackles the make-or-buy question from a strategic perspective (Chandler, 1962; Porter, 1985; Quinn, 1980). Strategy is the determinant of the basic long-term goals of a firm, and the adoption of actions and the allocation of resources necessary for carrying out these goals (Chandler, 1962). Miles and Snow (1978) identified four business-level strategies: defender, prospector, analyser, and reactor. Porter (1985) defined a five forces model which explains the strategic activities of a firm and proposes different perspectives, considering other factors besides cost reduction. Thus, innovation theories (Rogers, 1983) are taken into account within these four perspectives, and especially from a strategic viewpoint. Admittedly, the strategic perspective is intended to be interpreted to the strategic viewpoints, distinct from the resource-based view and transaction cost economics theories, because both incorporate also strategic perspectives.

The second approach aims to analyse the make-or-buy decision from a resource viewpoint (Barney, 1991; Penrose, 1959; Pfeffer \& Salancik, 1978; Thompson, 1967). First, the resource perspective plays an important role, especially in the RBV theory (Barney, 1991) and the resource dependency theory (Pfeffer \& Salancik, 1978). The RBV theory is a construct of competitive heterogeneity which can be applied for answering the question "Why do firms in the same industry vary systematically in performance over time?" According to RBV theories, this happens because internal capabilities and resources yield a competitive advantage. RBV adopts two assumptions in analysing sources: (1) firm resource heterogeneity and (2) firm resource immobility. There are four attributes of resources that lead to a competitive advantage: being valuable, rare, imperfectly imitable and non-substitutable. Second, the resource dependency theory states that firms depend to some degree on their external environment and external providers because they do not have all the resources they need. There are three core ideas in this theory: (1) social context matters; (2) organisations have strategies to enhance their autonomy and pursue interests; and (3) power is important for understanding internal and external actions of firms. Priem and Butler (2001) provided new insights for where and how the RBV can contribute, especially by complementary and integrated use of RBV together with other perspectives. 
The third strand addresses the make-or-buy question from a performance viewpoint. Key performance indicators should be defined and make-or-buy decisions evaluated. In addition to this, relationship theories (Klepper, 1995; Kern, 1997) can play a relevant role in the third and fourth perspectives. The research undertaken by Brewer, Ashenbaum and Carter (2013) validated and further developed the framework proposed by McIvor (2009) with performance attributes.

The fourth viewpoint approaches make-or-buy decisions from an uncertainty and opportunism perspective. TCE was established by Williamson $(1975,1981,1985)$ who stated in 1975 that the firm offers major governance over opportunism. Later on, Slater and Spencer (2000) emphasized the role of uncertainty as its core assumption. In fact, vertical integration stems as a preferred assessment to avoid contractual problems with external providers. The main theoretical argument of this theory is that the conditions of the transaction would lead to its internal, hybrid, or external governance. It has two important fundamental behavioural assumptions: (1) bounded rationality (Simon, 1957); and (2) opportunism. This risk of opportunism is a factor considered in the game (Fudenberg \& Tirole, 1990) and agency (Eisenhardt, 1989) theories (AT), which intend to safeguard firms from possible risks. When applied to make-or-buy studies, it posits that firms need to consider both production costs and transaction costs for an outsourcing negotiation.

\section{Data Collection Methods}

In order to develop, adapt and validate our conceptual framework, a number of interviews with practitioners and middle-level managers, and a set of interviews of an in-firm case study were undertaken. The interviews, the design of the interviews, the analysis of the transcripts and the incorporation of the findings into the framework are described here. Those experienced decision makers from the firms interviewed who are most willing to explain the decisions made at their workplace are selected. They are categorized into three levels: (DM1) who are represented by supply chain managers, purchasers and project leaders; DM2 represented by R\&D and industrial engineers; and DM3 represented by quality representatives. An analysis of the recent make-or-buy literature was performed and served as the basis for preparing and designing the interviews. From the beginning of data collection, we started to decide which information is relevant. Hypotheses collected from this literature review were contrasted with practitioners' opinions. Qualitative data analysis is conducted following the Miles and Huberman (1994) methodology, mainly: (1) Data reduction. In this phase, the mass of qualitative data obtained through interview transcripts, observations, notes, etc. is reduced and organised, and non-relevant data is discarded. (2) Data display. The analysis from mass data is displayed in the form of tables, charts and other graphical formats as a continual process. (3) Conclusion. The analysis review is the basis to begin to develop conclusions and to verify and validate the study. The meanings from the data are tested for their plausibility and their validity.

\subsection{Interviews with Practitioners}

Qualitative interviews were held with practitioners at supplier sites located in Europe. A Qualitative research was a better fit for the types of questions we were asking to provide us with the answers we were interested in. The interviews highlighted the essential importance of practitioners when developing the framework. In contrast to the research conducted by Cánez et al. (2000), who only considered the industrial context in the UK area for developing the framework, we interviewed practitioners located in Italy, the UK, Germany, Slovakia, the Netherlands, Belgium, Hungary and Poland. The 20 analysed firms are a convenient sample, since one of the authors has professional relationships with them. Information about the 20 firms analysed between 2016 and 2017 is drawn in Table 1. Practitioners are selected based on their experience on dealing with make-or-buy decisions and outsourcing transactions, who are mainly supply chain managers. Defined standardize interviewees based on a general methodology relied on a pre-designed questionnaire were undertaken in order to avoid bias and to be able to approach a qualitative comparison. Semi-structured interviews with middle-level managers were conducted. An interview questionnaire based on the literature was designed and used as an interview guide (Appendix I). One interview was performed per firm as part of an on-site supplier audit taking over one hour and mainly covering the following topics:

- Details of the interviewee

- Areas related to make-or-buy decisions 
- Triggers for make-or-buy decisions

- Criteria to be considered during the make-or-buy decision process

- Functions involved in the make-or-buy decision process

- Relevant criteria for the "make" and "outsourcing" decision taken at the organisation

- Relevant financial elements during the "make" and "buy" decision process

- Strengths and weaknesses of current and past decisions

- Lessons learned and suggestions of current and past decisions

\begin{tabular}{|c|c|c|c|c|}
\hline Firm & Sector & Plant & Revenue & No. of employees \\
\hline A & Electronics manufacturing & Slovakia & $€ 5-10 \mathrm{~m}$ & 200 \\
\hline B & Assembling & Germany & $€ 1-5 \mathrm{~m}$ & 170 \\
\hline $\mathrm{C}$ & Turning & Italy & $€ 37-40 \mathrm{~m}$ & 350 \\
\hline $\mathrm{D}$ & Die casting & Italy & $€ 5 \mathrm{~m}$ & 18 \\
\hline $\mathrm{E}$ & Turning, drilling, milling & UK & $£ 1.5 \mathrm{~m}$ & 24 \\
\hline $\mathrm{F}$ & Machining & UK & $£, 50 \mathrm{~m}$ & 328 \\
\hline G & Turning & Germany & $€ 5-10 \mathrm{~m}$ & $50-99$ \\
\hline $\mathrm{H}$ & Housing, metal processing & Germany & $€ 5-10 \mathrm{~m}$ & $50-99$ \\
\hline I & Metal powder forming & Netherlands & $\$ 5-10 \mathrm{~m}$ & $20-50$ \\
\hline $\mathrm{J}$ & Thermosets, plastics & Belgium & $\$ 100-500 \mathrm{~m}$ & 120 \\
\hline K & Housing, metal processing & Germany & $€ 50-100 \mathrm{~m}$ & 600 \\
\hline $\mathrm{L}$ & Sounders, loudspeakers & Italy & $€ 13 \mathrm{~m}$ & 50 \\
\hline M & Electronics manufacturing & Germany & $€ 140 \mathrm{~m}$ & 750 \\
\hline $\mathrm{N}$ & Electronics manufacturing & Germany & $€ 88 \mathrm{~m}$ & 700 \\
\hline $\mathrm{O}$ & Electrification & Hungary & $\$ 2.7 b$ & 13,500 \\
\hline $\mathrm{P}$ & Thermosets, plastics & Hungary & $€ 34 \mathrm{~m}$ & 450 \\
\hline Q & Die casting & Poland & $€ 10-25 \mathrm{~m}$ & 1,500 \\
\hline $\mathrm{R}$ & Turning & Italy & $€ 11.5 \mathrm{~m}$ & 50 \\
\hline $\mathrm{S}$ & Electrification & Germany & $\$ 33,828 \mathrm{~m}$ & 136,000 \\
\hline $\mathrm{T}$ & Die casting & Italy & $3.8 \mathrm{~m}$ & 40 \\
\hline
\end{tabular}

Table 1. Characteristics of interviewed firms, case study

\subsubsection{Findings and Results from the Interviews with Practitioners}

A number of issues arose from the analysis of the interviews. First, the principal triggers to undertake make-or-buy decisions were identified: (1) need for quality or delivery improvement; (2) need for proximity to markets; (3) need for cost or service improvement; (4) need for a competitive advantage; (5) new product or service introduction; (6) need for resources and skills at the firm; and (7) need for demand flexibility. Some of these triggers where mentioned in the past and their importance is supported by the practitioners involved in our research.

Second, the main factors considered for make-or-buy decisions were noted, for instance sales growth, profitability, costs reduction, manufacturing flexibility, core or non-core activity, technical differentiation, resource position, performance and the potential for opportunism. The "core or non-core activity" factor is a key decision criterion which strongly influences the make-or-buy decision. This relevance was noted in the discussion with the interviewees. As opposed to low-performance non-core activities, high-performance core or strategic activities should be retained in-house, if possible, in most cases. Data was summarised on an excel sheet and incorporated later in the preliminary framework. Data from the framework was continuously modified and updated. Third, key 
characteristics were highlighted on the excel sheet. The need for standardising the framework was always kept in mind. Thus, factors and triggers relevant for unusual circumstances and special use cases were remarked.

Finally, key issues related to the make-or-buy decision process were noted, such as the people involved, the durability of the project, and the difficulties found. A main differentiation can be observed between firms depending on their size, structure and internationalisation. In contrast to medium and small-sized firms, large and global players operating internationally have their strategic functions like procurement centralised. Local partnerships and long-term relationships are preferred once certain services have been outsourced. Mutual trust and clear and open bidirectional communication with external providers are key factors for outsourcing services like surface treatment, powder coating or assembling activities. The findings recorded in this section were also considered for improving the framework design.

\subsection{In-Firm Case Study}

In order to create a robust framework and a tool to help their functionality, several issues required to be addressed. First, a better understanding of how make-or-buy decisions were being made in practice was needed. Second, a better understanding of the lessons learned and improvement potentials collected from the interviews had to be analysed and prioritised. Third, a clear understanding of the interrelation between the firm, third parties and the triggers, factors and possible outcomes of each approach to make-or-buy decisions had to be identified. In order to do this, after the interviews with practitioners, twenty-four past and current make-or-buy decisions were analysed and reviewed using the framework (see Table 2).

\begin{tabular}{|c|c|c|c|c|c|c|c|}
\hline MoB & $\begin{array}{l}\text { Main } \\
\text { triggers }\end{array}$ & Main factors & $\begin{array}{l}\text { Sourcing } \\
\text { location }\end{array}$ & Sector & $\begin{array}{l}\text { Sourcing } \\
\text { strategy }\end{array}$ & $\begin{array}{l}\text { Production } \\
\text { output }\end{array}$ & R\&D output \\
\hline 1 & $\begin{array}{l}\text { Need for } \\
\text { quality } \\
\text { improvement }\end{array}$ & $\begin{array}{l}\text { Defects, } \\
\text { profitability }\end{array}$ & $\begin{array}{l}\text { Germany, } \\
\text { national \& } \\
\text { Slovakia }\end{array}$ & $\begin{array}{l}\text { Electronics } \\
\text { manufacturing }\end{array}$ & Multiple & $\begin{array}{l}\text { Investing to buy } \\
\text { from external } \\
\text { provider }\end{array}$ & $\begin{array}{l}\text { In-house } \\
\text { manufacturing }\end{array}$ \\
\hline 2 & $\begin{array}{l}\text { Need for } \\
\text { resources }\end{array}$ & $\begin{array}{l}\text { Resources, } \\
\text { profitability }\end{array}$ & $\begin{array}{l}\text { Abroad, } \\
\text { Czech } \\
\text { Republic }\end{array}$ & $\begin{array}{l}\text { Thermosets, } \\
\text { plastics }\end{array}$ & Single & $\begin{array}{l}\text { Investing to buy } \\
\text { from external } \\
\text { provider }\end{array}$ & $\begin{array}{l}\text { In-house } \\
\text { manufacturing }\end{array}$ \\
\hline 3 & $\begin{array}{l}\text { New product } \\
\text { introduction }\end{array}$ & $\begin{array}{l}\text { Supplier } \\
\text { process } \\
\text { maturity }\end{array}$ & $\begin{array}{l}\text { Abroad, } \\
\text { Slovenia }\end{array}$ & $\begin{array}{l}\text { Electronics } \\
\text { manufacturing }\end{array}$ & Single & $\begin{array}{l}\text { Investing to buy } \\
\text { from external } \\
\text { provider }\end{array}$ & $\begin{array}{l}\text { Hybrid } \\
\text { sourcing }\end{array}$ \\
\hline 4 & $\begin{array}{l}\text { Need for } \\
\text { resources }\end{array}$ & $\begin{array}{l}\text { Resources, } \\
\text { profitability }\end{array}$ & $\begin{array}{l}\text { Abroad, } \\
\text { Poland }\end{array}$ & $\begin{array}{l}\text { Thermosets, } \\
\text { plastics }\end{array}$ & Single & $\begin{array}{l}\text { Forming an } \\
\text { alliance }\end{array}$ & $\begin{array}{l}\text { In-house } \\
\text { manufacturing }\end{array}$ \\
\hline 5 & $\begin{array}{l}\text { Need for } \\
\text { resources }\end{array}$ & $\begin{array}{l}\text { Resources, } \\
\text { profitability }\end{array}$ & $\begin{array}{l}\text { Germany, } \\
\text { local }\end{array}$ & $\begin{array}{l}\text { Thermosets, } \\
\text { plastics }\end{array}$ & Single & $\begin{array}{l}\text { Investing to buy } \\
\text { from external } \\
\text { provider }\end{array}$ & $\begin{array}{l}\text { In-house } \\
\text { manufacturing }\end{array}$ \\
\hline 6 & $\begin{array}{l}\text { Need for } \\
\text { resources }\end{array}$ & $\begin{array}{l}\text { Resources, } \\
\text { profitability }\end{array}$ & $\begin{array}{l}\text { Germany, } \\
\text { local }\end{array}$ & $\begin{array}{l}\text { Thermosets, } \\
\text { plastics }\end{array}$ & Single & $\begin{array}{l}\text { Investing to buy } \\
\text { from external } \\
\text { provider }\end{array}$ & $\begin{array}{l}\text { In-house } \\
\text { manufacturing }\end{array}$ \\
\hline 7 & $\begin{array}{l}\text { Need for } \\
\text { resources }\end{array}$ & $\begin{array}{l}\text { Resources, } \\
\text { profitability }\end{array}$ & $\begin{array}{l}\text { Germany, } \\
\text { local }\end{array}$ & $\begin{array}{l}\text { Thermosets, } \\
\text { plastics }\end{array}$ & Single & $\begin{array}{l}\text { Investing to buy } \\
\text { from external } \\
\text { provider }\end{array}$ & $\begin{array}{l}\text { In-house } \\
\text { manufacturing }\end{array}$ \\
\hline 8 & $\begin{array}{l}\text { Need for } \\
\text { demand } \\
\text { flexibility }\end{array}$ & $\begin{array}{l}\text { Manufacturing } \\
\text { flexibility }\end{array}$ & $\begin{array}{l}\text { Germany, } \\
\text { local }\end{array}$ & Assembling & Multiple & $\begin{array}{l}\text { Buying from } \\
\text { external provider }\end{array}$ & $\begin{array}{l}\text { In-house } \\
\text { manufacturing }\end{array}$ \\
\hline 9 & $\begin{array}{l}\text { Need for } \\
\text { demand } \\
\text { flexibility }\end{array}$ & $\begin{array}{l}\text { Manufacturing } \\
\text { flexibility }\end{array}$ & $\begin{array}{l}\text { Germany, } \\
\text { local }\end{array}$ & Assembling & Multiple & $\begin{array}{l}\text { Buying from } \\
\text { external provider }\end{array}$ & $\begin{array}{l}\text { In-house } \\
\text { manufacturing }\end{array}$ \\
\hline
\end{tabular}




\begin{tabular}{|c|c|c|c|c|c|c|c|}
\hline MoB & $\begin{array}{l}\text { Main } \\
\text { triggers }\end{array}$ & Main factors & $\begin{array}{l}\text { Sourcing } \\
\text { location }\end{array}$ & Sector & $\begin{array}{l}\text { Sourcing } \\
\text { strategy }\end{array}$ & $\begin{array}{l}\text { Production } \\
\text { output }\end{array}$ & R\&D output \\
\hline 10 & $\begin{array}{l}\text { Need for } \\
\text { demand } \\
\text { flexibility }\end{array}$ & $\begin{array}{l}\text { Manufacturing } \\
\text { flexibility }\end{array}$ & $\begin{array}{l}\text { Germany, } \\
\text { local }\end{array}$ & $\begin{array}{l}\text { Surface } \\
\text { treatment }\end{array}$ & Multiple & $\begin{array}{l}\text { Buying from } \\
\text { external provider }\end{array}$ & $\begin{array}{l}\text { In-house } \\
\text { manufacturing }\end{array}$ \\
\hline 11 & $\begin{array}{l}\text { Need for } \\
\text { demand } \\
\text { flexibility }\end{array}$ & $\begin{array}{l}\text { Manufacturing } \\
\text { flexibility }\end{array}$ & $\begin{array}{l}\text { Germany, } \\
\text { national }\end{array}$ & $\begin{array}{l}\text { Surface } \\
\text { treatment }\end{array}$ & Multiple & $\begin{array}{l}\text { Buying from } \\
\text { external provider }\end{array}$ & $\begin{array}{l}\text { In-house } \\
\text { manufacturing }\end{array}$ \\
\hline 12 & $\begin{array}{l}\text { New service } \\
\text { introduction }\end{array}$ & $\begin{array}{l}\text { Contract } \\
\text { manufacturers' } \\
\text { capability }\end{array}$ & $\begin{array}{l}\text { Germany, } \\
\text { local }\end{array}$ & $\begin{array}{l}\text { Surface } \\
\text { treatment }\end{array}$ & Single & $\begin{array}{l}\text { Buying from } \\
\text { external provider }\end{array}$ & $\begin{array}{l}\text { In-house } \\
\text { manufacturing }\end{array}$ \\
\hline 13 & $\begin{array}{l}\text { Need for cost } \\
\text { or service } \\
\text { improvement }\end{array}$ & $\begin{array}{l}\text { Contract } \\
\text { manufacturers' } \\
\text { capability }\end{array}$ & $\begin{array}{l}\text { Germany, } \\
\text { local }\end{array}$ & $\begin{array}{l}\text { Metal powder } \\
\text { forming }\end{array}$ & Single & $\begin{array}{l}\text { Investing to buy } \\
\text { from external } \\
\text { provider }\end{array}$ & $\begin{array}{l}\text { In-house } \\
\text { manufacturing }\end{array}$ \\
\hline 14 & $\begin{array}{l}\text { New product } \\
\text { introduction }\end{array}$ & $\begin{array}{l}\text { Technical } \\
\text { differentiation, } \\
\text { core activity }\end{array}$ & Germany & $\begin{array}{l}\text { Thermosets, } \\
\text { plastics }\end{array}$ & Single & $\begin{array}{l}\text { Investing to } \\
\text { enable in-house } \\
\text { manufacturing }\end{array}$ & $\begin{array}{l}\text { In-house } \\
\text { manufacturing }\end{array}$ \\
\hline 15 & $\begin{array}{l}\text { New product } \\
\text { introduction }\end{array}$ & $\begin{array}{l}\text { Technical } \\
\text { differentiation, } \\
\text { core activity }\end{array}$ & Germany & $\begin{array}{l}\text { Thermosets, } \\
\text { plastics }\end{array}$ & Single & $\begin{array}{l}\text { Investing to } \\
\text { enable in-house } \\
\text { manufacturing }\end{array}$ & $\begin{array}{l}\text { In-house } \\
\text { manufacturing }\end{array}$ \\
\hline 16 & $\begin{array}{l}\text { New product } \\
\text { introduction }\end{array}$ & Sales growth & $\begin{array}{l}\text { Germany, } \\
\text { national }\end{array}$ & $\begin{array}{l}\text { Electronics } \\
\text { manufacturing }\end{array}$ & Single & $\begin{array}{l}\text { Investing to buy } \\
\text { from external } \\
\text { provider }\end{array}$ & $\begin{array}{l}\text { Hybrid } \\
\text { sourcing }\end{array}$ \\
\hline 17 & $\begin{array}{l}\text { New product } \\
\text { introduction }\end{array}$ & $\begin{array}{l}\text { Supplier } \\
\text { process } \\
\text { maturity }\end{array}$ & $\begin{array}{l}\text { Germany, } \\
\text { national }\end{array}$ & $\begin{array}{l}\text { Electronics } \\
\text { manufacturing }\end{array}$ & Single & $\begin{array}{l}\text { Investing to buy } \\
\text { from external } \\
\text { provider }\end{array}$ & $\begin{array}{l}\text { Hybrid } \\
\text { sourcing }\end{array}$ \\
\hline 18 & $\begin{array}{l}\text { Need for cost } \\
\text { or service } \\
\text { improvement }\end{array}$ & $\begin{array}{l}\text { Manufacturing } \\
\text { flexibility, cost } \\
\text { reduction }\end{array}$ & $\begin{array}{l}\text { Abroad, India } \\
\text { \& Germany }\end{array}$ & $\begin{array}{l}\text { Housing, metal } \\
\text { processing }\end{array}$ & Multiple & $\begin{array}{l}\text { Making } \\
\text { (subsidiary) \& } \\
\text { buying }\end{array}$ & $\begin{array}{l}\text { In-house } \\
\text { manufacturing }\end{array}$ \\
\hline 19 & $\begin{array}{l}\text { New tooling } \\
\text { introduction }\end{array}$ & $\begin{array}{l}\text { Resources, } \\
\text { profitability }\end{array}$ & $\begin{array}{l}\text { Germany, } \\
\text { national }\end{array}$ & Tooling & Single & $\begin{array}{l}\text { Buying from } \\
\text { external provider }\end{array}$ & $\begin{array}{l}\text { In-house } \\
\text { manufacturing }\end{array}$ \\
\hline 20 & $\begin{array}{l}\text { Need for } \\
\text { delivery \& } \\
\text { cost } \\
\text { improvement }\end{array}$ & $\begin{array}{l}\text { Competitive } \\
\text { advantage, } \\
\text { cost reduction }\end{array}$ & $\begin{array}{l}\text { Abroad, } \\
\text { Poland }\end{array}$ & $\begin{array}{l}\text { Housing, metal } \\
\text { processing }\end{array}$ & Single & $\begin{array}{l}\text { Investing to buy } \\
\text { from external } \\
\text { provider }\end{array}$ & $\begin{array}{l}\text { In-house } \\
\text { manufacturing }\end{array}$ \\
\hline 21 & $\begin{array}{l}\text { Need for cost } \\
\text { improvement }\end{array}$ & Cost reduction & $\begin{array}{l}\text { Germany, } \\
\text { national }\end{array}$ & $\begin{array}{l}\text { Electronics } \\
\text { manufacturing }\end{array}$ & Single & $\begin{array}{l}\text { Buying from } \\
\text { external provider }\end{array}$ & $\begin{array}{l}\text { In-house } \\
\text { manufacturing }\end{array}$ \\
\hline 22 & $\begin{array}{l}\text { New product } \\
\text { introduction }\end{array}$ & $\begin{array}{l}\text { Supplier } \\
\text { technology \& } \\
\text { manufacturing }\end{array}$ & $\begin{array}{l}\text { Germany, } \\
\text { local }\end{array}$ & $\begin{array}{l}\text { Housing, metal } \\
\text { processing }\end{array}$ & Single & $\begin{array}{l}\text { Buying from } \\
\text { external provider }\end{array}$ & $\begin{array}{l}\text { In-house } \\
\text { manufacturing }\end{array}$ \\
\hline 23 & $\begin{array}{l}\text { Need for } \\
\text { demand } \\
\text { flexibility }\end{array}$ & $\begin{array}{l}\text { Manufacturing } \\
\text { flexibility, cost } \\
\text { reduction }\end{array}$ & $\begin{array}{l}\text { Germany, } \\
\text { local }\end{array}$ & $\begin{array}{l}\text { Housing, metal } \\
\text { processing }\end{array}$ & Multiple & $\begin{array}{l}\text { Buying from } \\
\text { external provider }\end{array}$ & $\begin{array}{l}\text { In-house } \\
\text { manufacturing }\end{array}$ \\
\hline 24 & $\begin{array}{l}\text { New product } \\
\text { introduction }\end{array}$ & $\begin{array}{l}\text { Supplier } \\
\text { process } \\
\text { maturity }\end{array}$ & $\begin{array}{l}\text { Germany, } \\
\text { national }\end{array}$ & $\begin{array}{l}\text { Thermosets, } \\
\text { plastics }\end{array}$ & Single & $\begin{array}{l}\text { Buying from } \\
\text { external provider }\end{array}$ & $\begin{array}{l}\text { Hybrid } \\
\text { sourcing }\end{array}$ \\
\hline
\end{tabular}

Table 2. MoB decisions. Summarised outputs, case study

We collected information on how make-or-buy decisions were approached in several cases in order to undertake the in-firm case study. The information was obtained from a leading NEC, CEC, ATEX, GOST Inmetro and IECEx-certified manufacturer of electrical products. This firm, based in Germany, is a global player with 1,788 employees and a $€ 286.6$ million turnover (key figures from the end of 2016). The main criteria for selection were 
that the firm had recently assessed make-or-buy decisions and the convenience of one of the authors with the firm. The case study was carried out using evidences from multiple sources, such as make-or-buy decision assessments, final reports and project plans, for increased validity and reliability (Yin, 1994). The case study will also be useful to refine the framework and illustrate how to use it. A questionnaire with a preliminary framework was designed for the in-firm case study interviews, which covered the abovementioned topics and the discussion of the preliminary framework, the stages taken into account during the make-or-buy decision and an evaluation of the theories and hypotheses summarised from the make-or-buy literature review. Our questionnaire is based especially on the survey designed by Parmigiani (2007). (Appendix II).

\subsubsection{Findings and Results from the Case Study}

From the case study it was observed that firms preferable take make-and-buy strategies for complete solutions and services, but not for manufacturing single parts or components. However, hybrid sourcing is not commonly used by practitioners; firms can choose this option to get into new markets or for strategic reasons to increase their product brand portfolio. For instance, the firm based in Germany chose this option to supply their clients with particular cable glands with ATEX certification from a supplier who already certified these products and the firm sell them under its own brand's label name. In the past, individual managers have made the decision to pursue either a make or a buy strategy as a de-centralized activity at the middle- level manager, with little oversight of a strategic central sourcing function. The firm has a partly structured process for addressing make-or-buy decisions. However, there were clear problems with the control of documentation and the way make-or-buy decision processes were conducted and documented depending on the participants involved. In addition to this, interviewees proposed potential improvements to standardize the process. The involvement of a multidisciplinary team was mentioned by all interviewees. The firm manages its make-or-buy decisions from a centralized and strategic department and mostly is buying raw material, components and services for its production site. For instance, R\&D output column refers to the decision between insource or outsource the development of R\&D activities of a specific product or service. A key input collected from the analysed case study is the need to periodically evaluate the assessed make-or-buy decisions, document all changes requested in writing and reassess them if appropriate. Furthermore, the need for four stages in the decision-making process was identified in the study: (1) planning; (2) data collection and analysis; (3) performance evaluation; and (4) improvement.

\section{Proposed Framework}

The framework presented in this section has been developed using the data collected from the literature review, the qualitative interviews with practitioners described in Section 3.1 and a set of interviews of an in-firm case study explained in Section 3.2. Hence, the framework is in accordance with the guidelines proposed by Miles and Huberman (1984) and their implementation through Cánez et al. (2000) framework pointed out in Section 2.2. The framework explains graphically the main dimensions to be studied - the key factors, and the possible triggers and outcomes derived from make-or-buy decisions. The developed framework defines which dimensions are more important, which relationships are likely to be most meaningful, and what information should be collected. Four main strands identified in Section 2.2 and a number of factors observed in Section 3.1.1 were suggested within these clusters, including: (1) demand flexibility; (2) single or multiple source strategy; (3) trade implications; (4) technical differentiation; (5) competitive advantage; and (6) core / non-core product or service for the strategic value area. In opposite to Amit and Schoemaker (1993) who detailed the constructs of the resource-based view in combination with the behavioral decision theory, our framework priories the evaluation of key performance indicators during the make-or-buy decision. Within the resource position area the following factors were prioritised, mainly: (1) resources / capabilities available; (2) skills and know-how available; (3) assets available; (4) process maturity; (5) support systems; and (6) technology and manufacturing processes. While Shishank and Dekkers (2013) detailed a framework for new product development phase, our results from the case study confirmed that the most of the make-or-buy decisions happened during the manufacturing phase. Thus, costs saving strategies are pursued.

For the performance area, the following factors were noted: (1) conversion costs; (2) manufacturing flexibility; (3) contract cost reduction; (4) defective parts per million / ppm; (5) delivery reliability; (6) overall equipment effectiveness; (7) asset utilisation; (8) variant reduction; and (9) sustainability punctuation. In the potential for 
opportunism area, the following factors were proposed: (1) information asymmetry; (2) flexibility; (3) quality defects; (4) delivery delays; (5) cost increases; (6) skills appropriation; (7) insufficient corporate social responsibility (CSR) value; and (8) complexity of the relationship. Operational performance was regarded as an independent area, as an input concerning the improvement potential perceived by decision makers interviewed during the case study analysis. In fact, a performance assessment was a critical step missing in unstructured make-or-buy decision processes.

Possible influences from the external environment on the process are taken into account and included in the framework. As it was verified at the case study, our framework illustrated in Figure 1 validates the efficiency of the previous Cánez et al. (2000) approach, increasing the process's visibility for decision makers with the drawn possible outcomes.

External forces on which the firm's influence is minimal can activate triggers for the make-or-buy analysis and are illustrated in the framework. Therefore, firms can take advantage of external providers' expertise and a contractual cost reduction thanks to the economy of scale. In contrast to the existing make-or-buy decision-making approaches, our framework provides a practical and target-oriented overview, where decision makers can evaluate possible outcomes of the assessment from the start of the project. Interestingly, the graphical visualization of the framework allows academics and practitioners to locate the make-or-buy process for both R\&D and manufacturing activities.

A majority of studies highlighted the advantages of outsourcing for assessing non-core services and the vertical integration approach as a mechanism to safeguard core services and core products. For instance, in September 2017 the firm $\mathrm{ABB}$ announced the acquisition of the business unit of General Electrics, Industrial Solutions (Electrification-Switchgear-division). The main strategic goal was to successfully expand its market share in the US market and obtain the rights to use the GE brand.

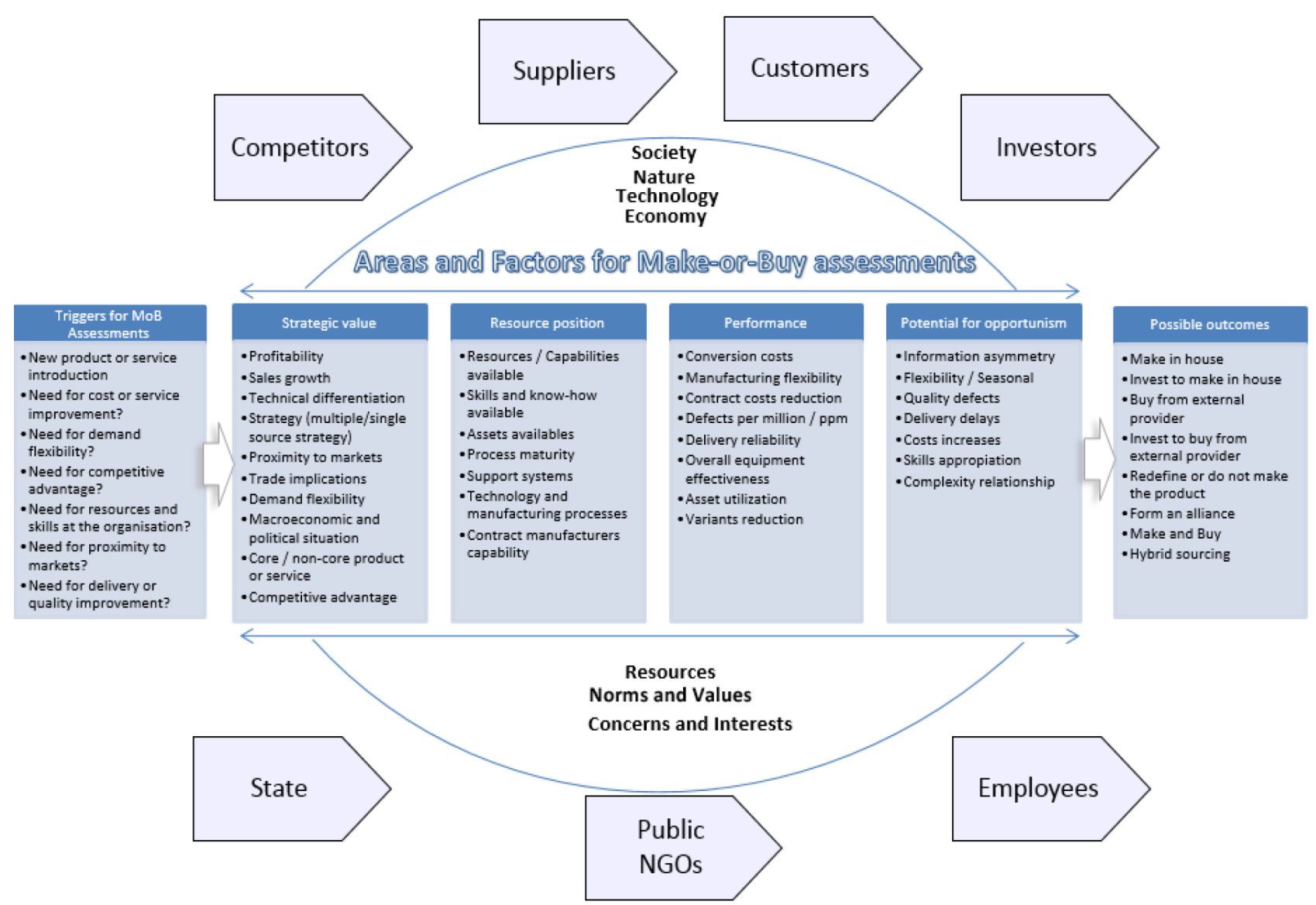

Figure 1. Make-or-buy framework, case study 
In addition to the one-page graphical illustration, a tool with a decision matrix was developed oriented towards the guidelines of the pairwise comparison technique (Thurstone, 1927) and the technique for order preference by similarity to ideal solution (TOPSIS) method. The pairwise comparison technique is widely employed to handle subjective and objective judgements in multi-criteria decision making, especially as a method to determine the weighting of criteria (Kou, Ergu \& Shang, 2014). The TOPSIS method has been dealt with multi-criteria models for complex decisions and multiple attribute models for the most preferable choice.

TOPSIS is a multi-criteria decision analysis method, which was originally developed by Hwang and Yoon (1981) with further developments by Yoon (1987) and Hwang, Lai and Liu (1993). This tool combines the pairwise comparison matrix and the TOPSIS method to enhance the tool's reliability in decision-making processes. The combination of both techniques enables the implementation of the framework. Interestingly, we define the criteria for the practical use of the tool as follows: (1) determining the weighting of criteria through a pairwise comparison matrix (PCM); (2) calculating the relative closeness to the ideal solution with a decision matrix based on the TOPSIS method; (3) determination of the weighting of decision makers; and (4) the criteria for the functionality of the tool (see Table 3). The weight of decision maker levels is set as follows according to the Boran, Genç, Kurt and Akay's (2009) research: DM1 is 0.406; DM2 is 0.238; and DM3 is 0.356, so that the total of the weighting is 1 .

\section{Pairwise comparison assessment:}

2 More important

1 Equally important

0 Less important

\section{Decision matrix assessment:}

5 The Excellence is achieved

4 The requirements are fully met

3 The requirements are almost completely fulfilled: it can be improved in the short term

2 The requirements are only partially met and / or improvement is only expected in the medium term

1 The requirements are not met, improvements are not expected

\begin{tabular}{l|c}
\hline 3. Determine the weighting of decision makers: & Weighting \\
Language terms: & 0.406 \\
DM1 Very important & 0.238 \\
DM2 Medium & 0.356 \\
DM3 Important
\end{tabular}

\section{Recommendations for results evaluation:}

Potential for make-or-buy decisions: High potential (Approved and preferred) Medium potential (Approved; decision is recommended) Low potential (decision is recommended, low risk involved) Recommended, high risk involved (proceed with caution or redefine your approach) Decision not recommended

\begin{tabular}{c}
$100 \%-80 \%$ \\
$80 \%-60 \%$ \\
$60 \%-40 \%$ \\
$40 \%-20 \%$ \\
$20 \%-0 \%$ \\
\hline
\end{tabular}

Table 3. Criteria for the operationalisation of the tool, case study

In the analysis, scores between $100 \%$ and $80 \%$ indicate that the assessment is highly recommended and scores between $80 \%$ and $60 \%$ indicate that decision is recommended, without risks involved. If scores between $60 \%$ and $40 \%$ are obtained the decision is recommended (although low risk exists), whereas the risk for the assessment is high when scores are between $40 \%$ and $20 \%$. Finally, the decision for scores lower than $20 \%$ is not recommended. If several source alternatives obtain scores within the $100 \%-80 \%$ range, make-and-buy decisions, hybrid sourcing and alliance options should be evaluated according to the key objectives defined in the tool. The project leader, assigned for the make-or-buy decision, planned, coordinated and led activities to ensure that tasks were accomplished according to the milestone plan and all key deadlines were met. The project was documented 
on a project sheet containing the following sections: (1) general information; (2) key objectives; (3) required criteria; (4) pairwise comparison assessment (Figure 2); and (5) TOPSIS decision matrix sheet (Figure 3).

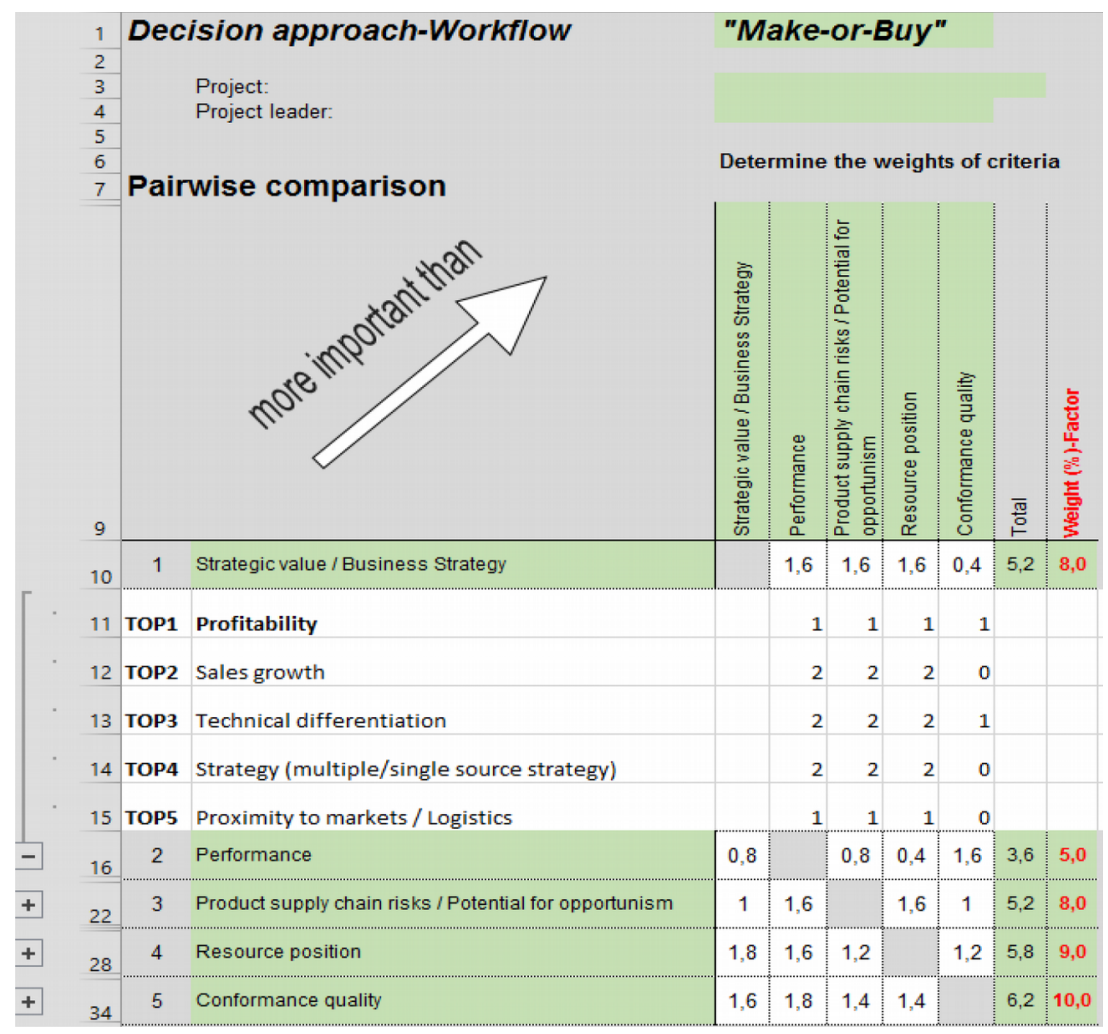

Figure 2. Pairwise comparison, case study

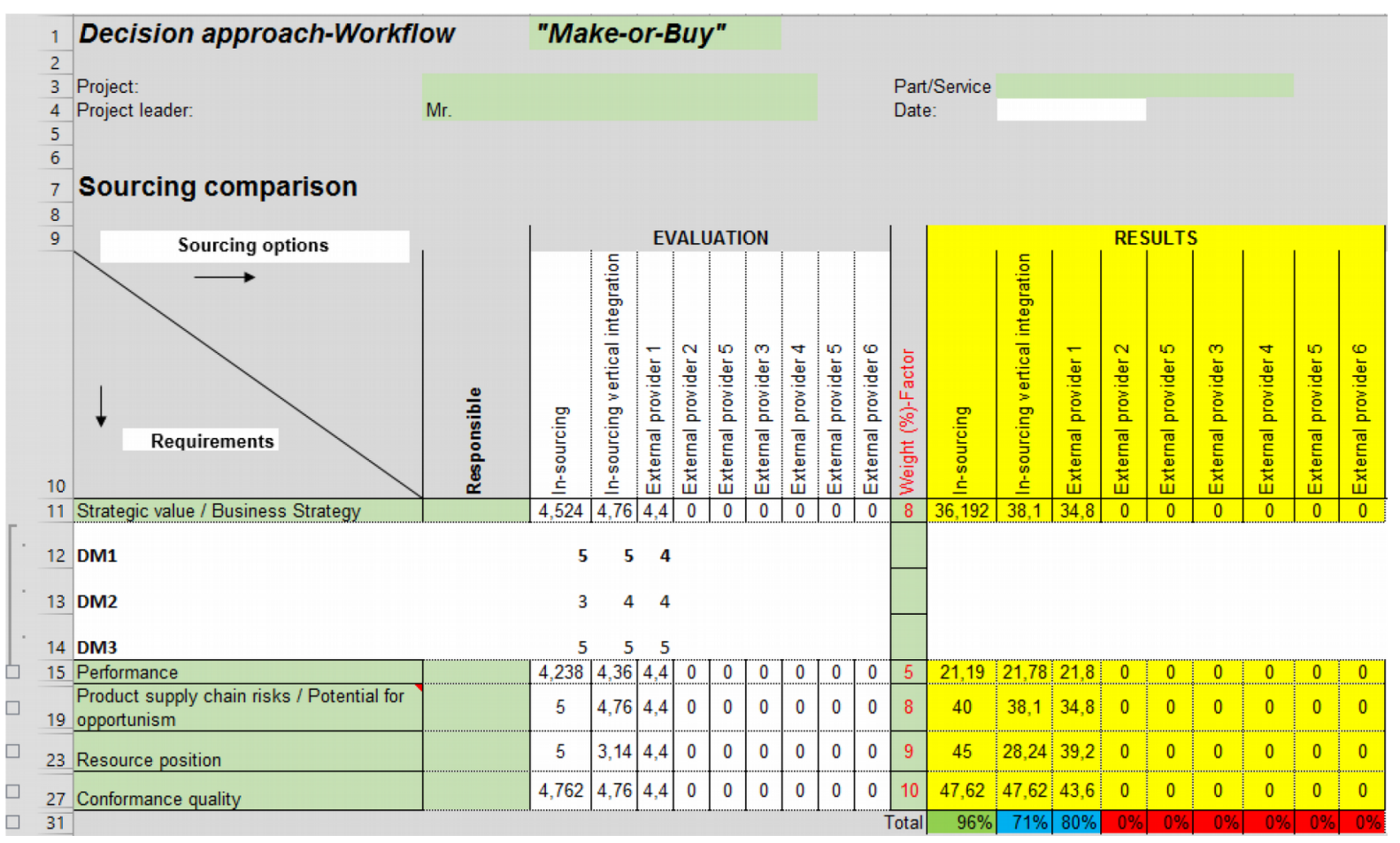

Table 3. Criteria for the operationalisation of the tool, case study 


\subsection{An Illustration of the Framework Using a Case Study}

This section shows how this framework and its content are align with the considerations of the discussed in-firm case study. The triggers, the external elements which activate the triggers, the areas and factors and the final outcomes of the case study are discussed in this section.

\subsubsection{First MoB Case Study}

\subsubsection{Firm and Environment}

The first make-or-buy (MoB) case study was related to the manufacturing of electronic isolators involving PCB (printed circuit board) assembly and painting and the respective functional and in-circuit tests. The R\&D and the manufacturing of those products were performed in the firm. The high number of quality issues in the production line and the high failure rate of the manufactured isolators made upper management aware of this issue, which led to force quality improvements and pressure to reduce rework costs.

\subsubsection{Triggers}

From the analysis of the case, it was clear that the main trigger for the make-or-buy review was the need for quality improvement and the reduction of rework costs. When the manufacturing process was examined, three needs were identified: investment in high-tech machinery, process standardisation and training of the people involved. The high number of variants and their complexity hindered the process and required further resources which were not available at the firm. As a result of this, a multidisciplinary team was set up to conduct the make-or-buy analysis.

\subsubsection{Considerations for the Make-or-Buy Decision}

Strategic value. These parts provide a clear competitive advantage and have a relatively high strategic value for the firm because of their technical differentiation against competitors. This was a relevant factor, together with the need for a profitability increase, a multiple sourcing strategy and demand flexibility.

Resource position. The firm's low resource position required additional investment in high-tech assets and internal resources, but other important considerations were the availability of contract manufacturers in the market offering advanced technology and expertise in similar industrial processes. Hence, given the small volume of parts manufactured per year, the high investment required would not be recovered by the firm. Special certifications and compliance with technical requirements would require a support system and team for potential future external providers if it were decided to outsource the manufacturing process.

Performance. The internal process performance was low and partly not measured because of the process was not mature. The definition of key performance indicators (KPIs) to monitor the process was essential to evaluate the outcome decision. Contract cost reduction indicators, delivery and quality performance figures, asset utilisation and variant reduction were taken into account. The firm could take advantage of the economy of scale by reducing its manufacturing costs.

Information asymmetry was a clear problem which was not totally identified during the make-or-buy decision-making process because of the firm failed to clearly and comprehensively document all specifications for external providers. The risk for an increase in quality defects, purchasing costs, delivery delays and a complex relationship with external providers were also factored in. Additionally, monitoring and auditing activities would be required in order to support the external provider until the process had been matured at its site.

\subsubsection{Final Outcome}

In this case study, the final decision was to switch from manufacturing the part in-house to source the activity out split for two external providers. The volume of the activity was equally outsourced by approximately $50 \%$ of the revenue between both external providers. The firm got a better negotiation position with them because of the possibility to assign each stage of the process to one or other external provider. Fact, that was feared by the external providers. 


\subsubsection{Lessons Learned}

According to interviewees, the make-or-buy decision process could be improved if all drawings, test specifications, control plans and FMEAs (Failure modes and effects analysis) were previously available and clearly documented. Specifications were only written in the German language, which created some misunderstandings for one external provider located abroad. Many test criteria were not clearly documented, leading to misunderstandings between the parties. A change process for outsourced products was not implemented, which gave rise to many unexpected costs as a result of the high number of product change requests. Interestingly, asymmetry and poor information issues could be avoided. It's observed that firms performed weakly on the control of the outsourced activities (Dekkers, 2011).

\section{Discussion}

Why is a make-or-buy decision a dilemma for firms? The difficult choice of whether to keep key functions, manufacturing or R\&D activities in-house or outsource them has taken centre stage in firms. Firms can reach their own strategy and goals by saving costs and increasing profits through resolving make-or-buy decisions in a proper manner. Is it merely a decision how to source processes or components (parts, materials)? It's not only a merely decision, it's an established process within the firm. This paper contributes to spread out the academic understanding and practitioners' knowledge by means of a framework and its operationalisation. Particular attention is paid to the assessment and implementation of the framework via the developed tool enabling practitioners and academics to visualise the possible outcomes of make-or-buy assessments. The main figures of the twenty-four $\mathrm{MoB}$ decisions were documented and described using the framework. Only one of them was described in detail because of the paper's size limitations. Besides the traditional pure sourcing strategy, other options are considered: plural sourcing strategies, hybrid sourcing and the formation of alliances. Hybrid sourcing is preferred when a great degree of cooperation and coordination between firms and external providers exists. External factors derived from the power and politics theories (Pfeffer, 1981, 1982) can influence these approaches. A proper explanation how each areas and attributes are affecting make-or-buy decisions individually was required. From the research study was identified that the need to comply with the quality is the most significant attribute, ahead by the resource position of the sourcing, followed by the potential for opportunism and the strategic value, and ended by the performance attributes.

In plural sourcing, the combination of complementarities and constraints determines the optimal mix of internal and external sourcing. In addition to this, when the effects of the combination of both forces are equal to the effects of transactional hazards, plural sourcing is suggested. Even two of the most significant conclusions for practitioners concern the need to design a structured make-or-buy decision process and the fit between the required characteristics of both the people conducting the make-or-buy decision process and the actual characteristics of the people involved in the process (Boer \& During, 2001) were already studied. Our study validates them and confirms the importance of involving a multidisciplinary team and a project leader in charge of carrying out the make-or-buy assessment, allocating timescales and responsibilities and evaluating the way team member perceptions influence on the process. Our empirical results support the findings from Medina-Serrano, González-Ramírez and Gascó-Gascó (2018) concerning the relevance to evaluate the will to collaborate and joint problem solving in order to improve the partnership on outsourcing transactions. The risk of make-or-buy decisions is identified and should be taken into account. Whereas a wrong "buy" approach can lead to an increase in quality defects, purchasing costs, delivery delays, and losing knowledge, an appropriate "make" approach can safeguard stakeholder's long-term strategy. Thus, the role of stakeholders has a direct influence on make-or-buy decisions and on overall chain, as this is a strategic attribute. The $\mathrm{MoB}$ decisions analyzed within this case study suggest that the framework is comprehensive and includes the key considerations highlighted in the interviews, offering insights about possible outcomes.

As observed in the case study, while the relevance of business strategy is greater than or equal to that of economic factors, the risks involved in product supply chains are quite relevant. What are the main reasons for outsourcing? The outsourced area was a major problem for the firm in the past, partly because of the small volume of parts needed. The wish to sustain a multiple source policy, reduce costs, improve flexibility, exploits management's expertise of contractors, avoid investment and outsource non-core activities to focus on core 
activities are some of the reasons for outsourcing provided in the case study. What costs are more relevant for the "buy" analysis? Increased purchasing expenses, the purchase price of the part, transportation expenses, any service or quality-related follow-up costs, complaint costs, receiving and inspection expenses, future pricing proposed by the provider, costs that the firm would keep incurring in the future, ongoing costs, one-time costs and auditing costs were considered. What financial factors are relevant in an organisation during the "make" decision process? Raw material costs, invested capital, labour costs, overhead costs and poor information were taken into consideration.

\section{Conclusions}

The research presented in this paper has significant theoretical and practical implications in the supply chain area in general and procurement management in particular, extending past versions of multi-criteria decision-making. Although past literature reviews provide valuable results, they were based upon the assessment of make-or-buy decisions failing to consider plural sourcing, hybrid sourcing or forming alliances. This paper aims to contribute to the study of the make-or-buy literature in supply chain management through the graphical representation of why and how make-or-buy decisions are made. Interestingly, the paper presents relevant dimensions and factors to be studied and evaluates possible outcomes when approaching make-or-buy decisions. The proposed framework is verified and validated by the internal released and implementation in the aforementioned firm based in Germany. Interestingly, our framework seems to extend, update and validate the proposed framework from Cánez et al. (2000). In contrast to their approach, our framework can be applied by practitioners and academics through its implementation into the pairwise and decision matrix tools. Our results support the Shishank and Dekkers' (2013) statement that a structured and standardize process is required in order to avoid resolving make-or-buy decisions under the conditions of inaccurate and incomplete information.

Due to the contradictory prescriptions of the McIvor (2009) and Brewer, Ashenbaum and Carter (2013) frameworks, our framework not only includes relevant factors to be considered, but also provides a structure to investigate these factors and design a practical decision matrix with a pairwise comparison to put the framework into practice. This is supported by the make-or-buy decision-making processes reviewed in the in-firm case study. Additionally, it takes into account the need to determine the weighting of decision makers, as seen in the case study, and comprehensively and understandably document the completed make-or-buy decision-making process through the project sheet and the project report. Further testing of the tool involving the parameters defined in the designed framework is addressed during its implementation.

The integration of the framework within the proposed tool provides decision makers, practitioners and academics with a practical solution to make decisions in a structured and consistent manner. As observed in the case study, a better understanding of the lessons learned and improvement potentials should be considered for every future MoB decision. Hence, practitioners can learn from past failures by adapting future requirements and continuously updating the proposed framework and tool. Since the objective of this study is to create a decision model to support strategic sourcing decisions, the research approach presented here is suitable. The research approach will involve a two-stage decision process: the make-or-buy decision and the managerial actions required to implement the decision.

Admitting the described findings and contributions, this research faced a number of limitations and so do its outcomes. For instance, a potential limitation of this research stems from the fact that the presented analysis is focused on a set of in-firm make-or-buy decisions from the firm's perspective. Subsequently, the comparison with other case studies was not evaluated and it would be suggested to compare it with other case studies and other branches and regions.

\section{Declaration of Conflicting Interests}

The authors declared no potential conflicts of interest with respect to the research, authorship, and/or publication of this article.

\section{Funding}

The authors received no financial support for the research, authorship, and/or publication of this article. 


\section{References}

Amit, R., \& Schoemaker, P.J.H. (1993). Strategic assets and organizational rent. Strategic Management Journal, 14(1), 33-46. https://doi.org/10.1002/smj.4250140105

Apte, U.M., \& Mason, R.O. (1995). Global Disaggregation of Information Intensive Services. Management Science, 41(7), 1250-1262. https://doi.org/10.1287/mnsc.41.7.1250

Barney, J.B. (1991). Firm Resources and Sustained Competitive Advantage. Journal of Management, 17(1), 99-120. https://doi.org/10.1177/014920639101700108

Boer, H., \& During, W.E. (2001). Innovation, What Innovation? A Comparison between Product, Process and Organizational Innovation. International Journal of Technology Management, 22, 83-107. https://doi.org/10.1504/IJTM.2001.002956

Boran, F.E., Genç, S., Kurt, M., \& Akay, D. (2009). A multi-criteria intuitionistic fuzzy group decision making for supplier selection with TOPSIS method. Expert Systems with Applications, 36(8), 11363-1368. https://doi.org/10.1016/j.eswa.2009.03.039

Brem, A., \& Elsner, R. (2018). Make-or-buy decisions on technology-intensive products: Insights from the consumer goods industry. International Journal of Innovation Management, 1850046 (17 pages). https://doi.org/10.1142/S1363919618500469

Brewer, B.L., Ashenbaum, B., \& Carter, J.R. (2013). Understanding the supply chain outsourcing cascade: when does procurement follow manufacturing out the door? Journal of Supply Chain Management, 49(3), 90-110. https://doi.org/10.1111/jscm.12021

Butkovic, L.L., Kauric, A.G., \& Mikulic, J. (2016). Supply chain management in the construction industry-A literature review. Paper presented at the 798-811. Available at: https://search.proquest.com/docview/1803688409?accountid=17192

Cánez, L.E., Platts, K.W., \& Probert, D.R. (2000). Developing a framework for make-or-buy decisions. International Journal of Operations and Production Management, 20(11), 1313-1330. https://doi.org/10.1108/01443570010348271

Chandler, A.D. (1962). Strategy and Structure. Cambridge, MA: MIT Press.

Dekkers, R. (2011). Impact of strategic decision making for outsourcing on managing manufacturing. International Journal of Operations and Production Management, 31(9), 935-965. https://doi.org/10.1108/01443571111165839

Dibbern, J., Goles, T., Hirschheim, R., \& Jayatilaka, B. (2004). Information Systems Outsourcing: A Survey and Analysis of the Literature. Data Base for Advances in Information Systems, 35(4), 6-102. https://doi.org/10.1145/1035233.1035236

Doz, Y., Prahalad, C.K., \& Hamel, G. (1990). Control, change and flexibility: the dilemma of transnational collaboration. In Bartlett, C.A., Doz, Y., \& Hedlund, G. (Eds.), Managing the Global Firm (117-143). London: Routledge..

Eisenhardt, K.M. (1989). Agency Theory: An Assessment and Review. Academy of Management Review, 14(1), 57-74. https://doi.org/10.5465/amr.1989.4279003

Fudenberg, D., \& Tirole, J. (1990). Noncooperative Game Theory for Industrial Organization. In Schmalensee, R., \& Willig, R.D. (Eds.), Handbook of Industrial Organizations (1, 259-327). New York, Oxford, Tokyo. https://doi.org/10.1016/S1573-448X(89)01008-3

Hwang, C.L., Lai, Y.J., \& Liu, T.Y. (1993). A new approach for multiple objective decision making. Computers and Operational Research, 20, 889-899. https://doi.org/10.1016/0305-0548(93)90109-V

Hwang, C.L., \& Yoon, K. (1981). Multiple Attribute Decision Making: Methods and Applications. New York: Springer-Verlag. https://doi.org/10.1007/978-3-642-48318-9

Jacobides, M.G., \& Hitt, L.M. (2005). Losing sight of the forest for the trees? Productive capabilities and gains from trade as drivers of vertical scope. Strategic Management Journal, 26(13), 1209-1227. https://doi.org/10.1002/smj.501 
Kern, T. (1997). The Gestalt of an information Technology Outsourcing Relationship: an Exploratory analysis. Proceeding of the $18^{\text {th }}$ International Conference on Information Systems. Atlanta, Georgia.

Klepper, R. (1995). The Management of Partnering Development in I/S Outsourcing. Journal of Information Technology, 10(4), 249-258. https://doi.org/10.1177/026839629501000405

Kou, G., Ergu, D., \& Shang, J. (2014). Enhancing data consistency in decision matrix: Adapting Hadamard model to mitigate judgment contradiction. European Journal of Operational Research, 236, 261-271.

https://doi.org/10.1016/j.ejor.2013.11.035

McIvor, R.T., Humphreys, P.K., \& McAleer, W.E. (1997). A strategic model for the formulation of an effective make-or-buy decision. Management Decision, 32(2), 169-178. https://doi.org/10.1108/00251749710160331

McIvor, R. (2009). How the transaction cost and resource-based theories of the firm inform outsourcing evaluation. Journal of Operations Management, 27(1), 45-63. https://doi.org/10.1016/j.jom.2008.03.004

McIvor, R. (2013). Understanding the manufacturing location decision: the case for the transaction cost and capability perspectives. Journal of Supply Chain Management, 49(2). https:// doi.org/10.1111/jscm.12010

Medina-Serrano, R., González-Ramírez, M.R., \& Gascó-Gascó, J.L. (2018). Should we make or buy? An update and review. European Research on Management and Business Economics, 24(3), 137-148.

https://doi.org/10.1016/j.iedeen.2018.05.004

Miles, M.B., \& Huberman, A.M. (1984). Qualitative Data Analysis. London: Sage Publications.

Miles, M.B., \& Huberman, A.M. (1994). Qualitative Data Analysis (2nd ed.). Thousand Oaks, CA: Sage Publications.

Miles, R., \& Snow, C. (1978). Organizational Strategy, Structure and Process. New York: McGraw-Hill. https://doi.org/10.2307/257544

Park, J.K., \& Ro, Y.K. (2011). The impact of a firm's make, pseudo-make, or buy strategy on product performance. Journal of Operations Management, 29(4), 289-304. https://doi.org/10.1016/j.jom.2010.08.004

Parmigiani, A. (2007). Why Do Firms Both Make and Buy? An Investigation of Concurrent Sourcing. Strategic Management Journal, 28(3), 285-311. https:// doi.org/10.1002/smj.580

Penrose, E.T. (1959). The Theory of the Growth of the Firm. New York: Blackwell.

Pfeffer, J. (1981). Power in Organizations. Marshfield, Mass: Pitman Pub.

Pfeffer, J. (1982). Organizations and Organization Theory. Boston: Pitman.

Pfeffer, J., \& Salancik, G.R. (1978). The External Control of Organizations: A Resource Dependence Perspective. New York: Harper \& Row.

Porter, M.E. (1985). Competitive Advantage: Creating and Sustaining Superior Performance. New York, London: Free Press, Collier Macmillan.

Priem, R.L., \& Butler, J.E. (2001). Is the Resource-Based "View" a Useful Perspective for Strategic Management Research? Academy of Management Review, 26(1), 22-40. https:/ / doi.org/10.5465/amr.2001.4011928

Puranam, P., Gulati. R., \& Bhattacharya, S. (2013). How much to make and how much to buy? An analysis of optimal plural sourcing strategies. Strategic Management Journal, 34(10), 1145-1161. https://doi.org/10.1002/smj.2063

Quinn, J.B. (1980). Strategies for Change: Logical Incrementalism. Homewood, Ill: Richard D. Irwin.

Quinn, J.B., \& Hilmer, F.G. (1994): Strategic Outsourcing. Sloan Management Review, 35(4), 43-55.

Rogers, E.M. (1983). Diffusion of Innovations. New York: The Free Press.

Simon, H.A. (1957). Models of Man: Social and Rational. New York: Wiley. https://doi.org/10.2307/2550441

Shishank, S., \& Dekkers, R. (2013). Outsourcing: decision-making methods and criteria during design and engineering. Production Planning and Control: The Management of Operations, 24(4-5), 318-336.

https://doi.org/10.1080/09537287.2011.648544 
Sislian, E., \& Satir, A. (2000). Strategic sourcing: A framework and a case study. Journal of Supply Chain Management, 36(3), 4-11. https://doi.org/10.1111/j.1745-493X.2000.tb00246.x

Slater, G., \& Spencer, D.A. (2000). The Uncertain Foundations of Transaction Cost Economics. Journal of Economic, 34(1), 61-87. https://doi.org/10.1080/00213624.2000.11506244

Thompson, R.L. (1967). Organizations in Action. New York: McGraw-Hill.

Thurstone, L.L. (1927). A law of comparative judgment. Psychological Review, 34(4), 273-286. https://doi.org/10.1037/h0070288

Venkatesan, R. (1992). Strategic sourcing: to make or not to make. Harvard Business Review, November-December, 98-107.

Walker, G. (1988). Strategic Sourcing, Vertical Integration, and Transaction Costs. Interfaces, 18(3), 62-73. https://doi.org/10.1287/inte.18.3.62

Welch, J.A., \& Nayak, P.R. (1992). Strategic Sourcing: A Progressive Approach to the Make or Buy decision, Academy of Management Executive, 6(1), 23-31. https://doi.org/10.5465/ame.1992.4274302

Williamson, O.E. (1975). Markets and Hierarchies, Analysis and Antitrust Implications: A Study in the Economics of Internal Organization. New York: Free Press.

Williamson, O.E. (1981). The Economics of Organization: The Transaction Cost Approach. American Journal of Sociology, 87(3), 548-577. https://doi.org/10.1086/227496

Williamson, O.E. (1985). The Economic Institutions of Capitalism: Firms, Markets, Relational Contracting. New York, London: Free Press, Collier Macmillan.

Yin, R. (1994). Case study research. London: Sage Publications.

Yoon, K. (1987). A reconciliation among discrete compromise situations. Journal of Operational Research Society, 38, 277-286. https://doi.org/10.1057/jors.1987.44

\section{Appendix I. Questionnaire: interview with industrialists}

- Details of the interviewee;

- Areas related to make-or-buy decisions;

\section{What of the following performance criterias are taken into account at your organisation during the "Make or Buy" decision process?}

\begin{tabular}{|c|c|c|}
\hline & Less relevant & More relevant \\
\hline Manufacturing flexibility & & 0 \\
\hline Costs reduction & & 0 \\
\hline $\begin{array}{l}\text { Quality defects / like } \\
\text { Defects per million }\end{array}$ & & \\
\hline Delivery reliability & & \\
\hline $\begin{array}{l}\text { Overall equipment } \\
\text { effectiveness }\end{array}$ & & \\
\hline Risk to core capabilities & D & $\checkmark$ \\
\hline Technical differentiation & & ( \\
\hline Other, please specify & & \\
\hline
\end{tabular}


2. Which of the following criterias for the "make analysis" are more relevant at your organisation?

\begin{tabular}{l} 
In-house process \\
differentiates the product \\
Need to "push the \\
technology envelope" \\
Few or no alternative \\
sources of supply \\
Imperative to couple supply \\
and usage (real-time/ short \\
lead time) for quick \\
response or quality \\
Internally cost advantaged \\
or at partly, high quality \\
Manufacturing investments \\
meet required return on \\
invested capital \\
Company has strong, \\
defensible skill base \\
Other, please specify \\
\hline
\end{tabular}

3. Which reasons for outsourcing are more relevant at your organisation?

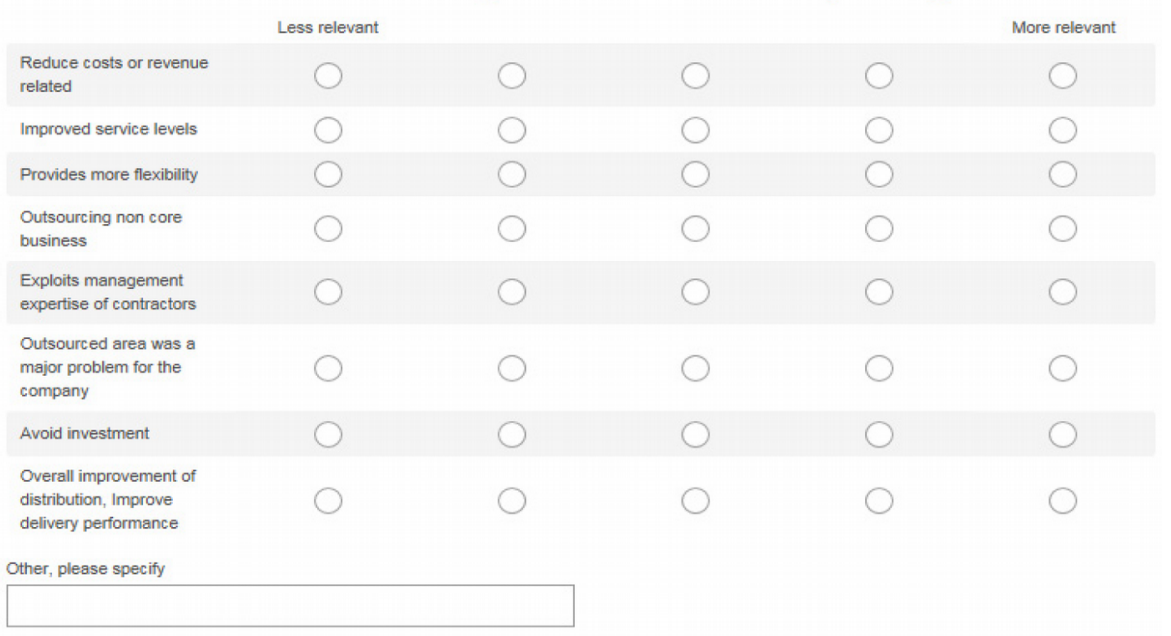

4. What of the following considerations are taken into account at your organisation duing the "Make or Buy" decision process?

\begin{tabular}{l} 
\#High strategic importance, \\
core business + \#High \\
contribution to operational \\
performance \\
\#High strategic importance, \\
core business + \#Low \\
contribution to operational \\
performance \\
\#Low strategic importance, \\
non core business + \#High \\
contribution to operational \\
performance \\
\#Low strategic importance, \\
non core business + \#Low \\
contribution to operational \\
performance, item not \\
necessary to the firm's \\
strategy \\
Other ,please specify \\
\hline
\end{tabular}


5. Which of the following stages are taken into account during the make or buy decision process at your organisation?

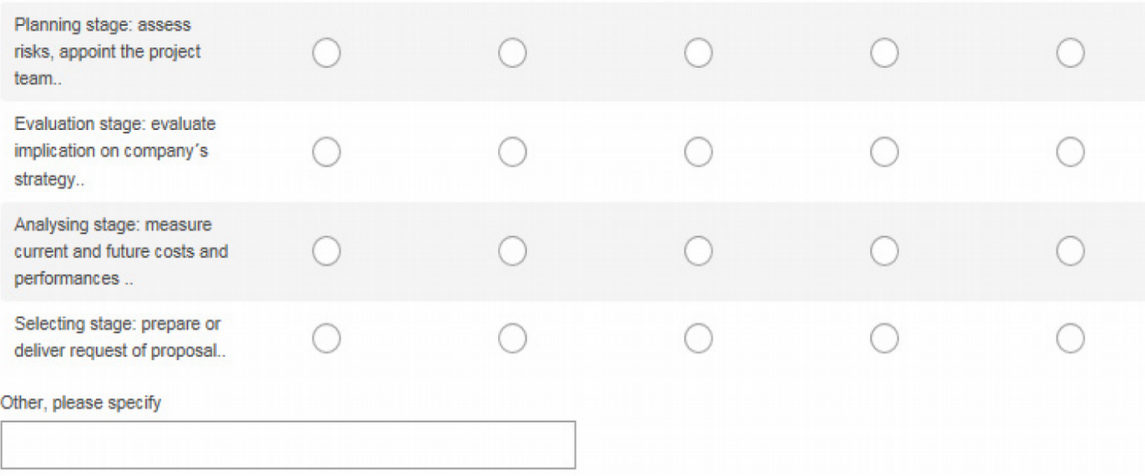

6. Which financial elements are relevant at your organisation during the "make-it" decision process?

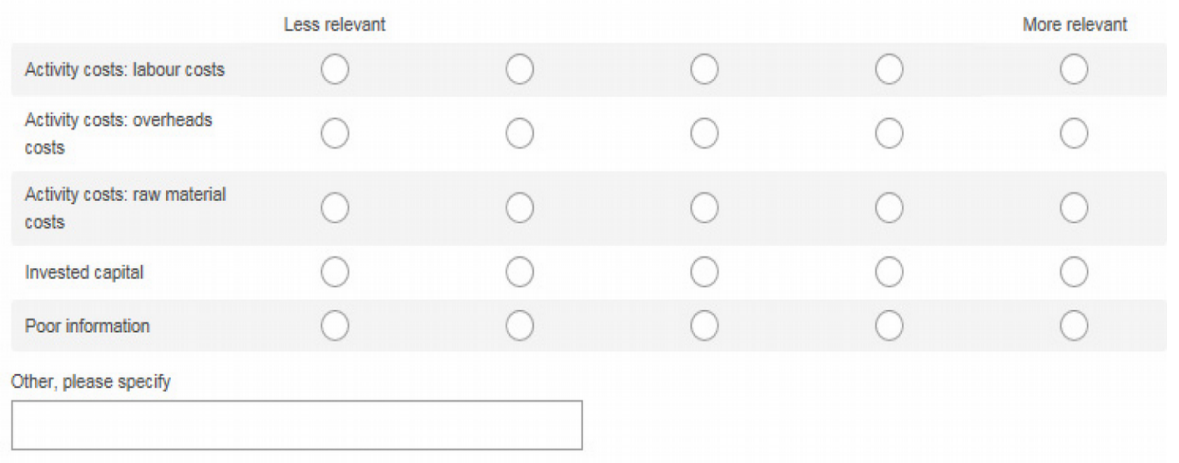

7. Which financial elements are relevant at your organisation during the "buy-it" decision process?

Provider's proposal
$\begin{aligned} & \text { Future pricing in provider's } \\ & \text { proposal }\end{aligned}$
Costs that don't disappear
One-time costs
Ongoing and hidden costs
Auditing and surveillance
costs
Other, please specify




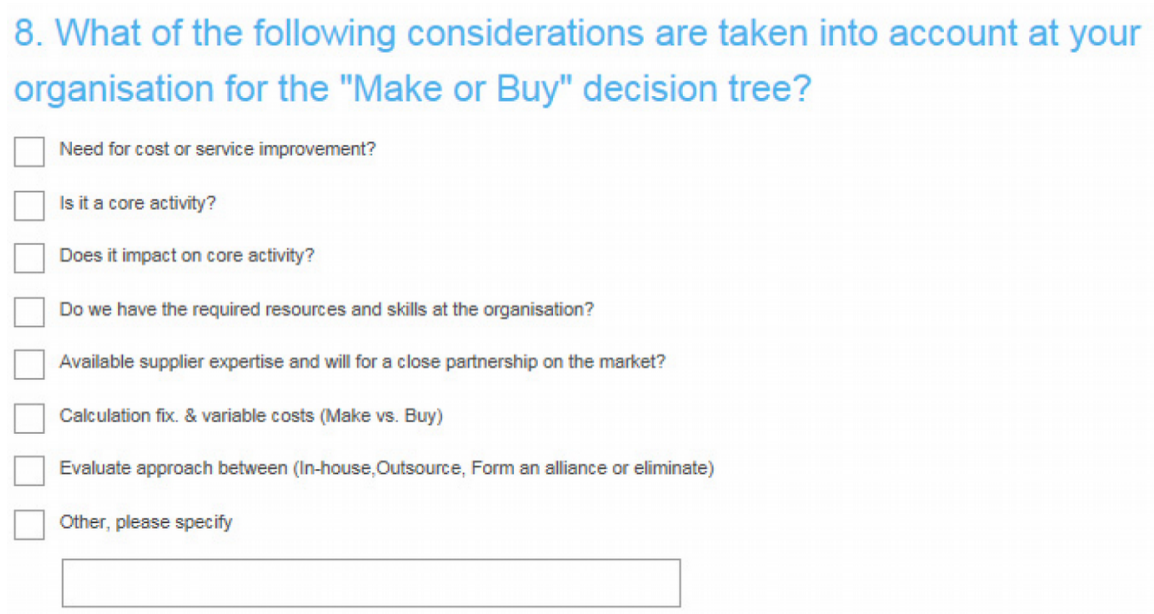

\section{Appendix II. Survey: case study guide}

1. For the past fiscal year, which best describes how you source progressive X-parts (enclosures)?

1. All done internally (either within your plant or from a division with which your firm shares a common corporate parent)

2. All purchased from external suppliers

3. Both done internally and purchased from external suppliers

(i) If you marked this response, what $\%$ of your requirements did you produce internally? (Please mark one)

$0 \%-10 \%$
$26 \%-49 \%$
$75 \%-90 \%$
$11 \%-25 \%$
$50 \%-74 \%$

Over $90 \%$

Do not use this input

\section{Independent variables}

Each item included a response scale of 1 to 7 , indicating totally true to totally untrue. Items were edited to reflect each different good (e.g., 'dies').

Asset specificity

1. The skills needed to create dies are generic and widely available (reversed) (Parmigiani, 2007).

2. Numerous capable die suppliers exist in the market (Walker and Weber, 1984; reversed).

3. Switching die suppliers would be quick and easy to do (Poppo and Zenger, 1998; reversed).

\section{Volume uncertainty}

1. Our forecasts for dies are very accurate (Anderson and Weitz, 1986; reversed).

2. There are predictable patterns to our requirements (Anderson and Weitz, 1986; reversed).

\section{Technological uncertainty}

1. The processes and skills required to create dies are mature and unlikely to change in the future (Heide and Weiss, 1995; reversed).

2. Major die innovations are very likely within the next few years (Bensaou and Anderson, 1999). 
3. Major innovations in how dies are produced are very likely within the next few years (Bensaou and Anderson, 1999).

\section{Performance uncertainty}

1. We can easily describe dies to our suppliers through printed/electronic descriptions and/or drawings (reversed) (Parmigiani, 2007).

2. Through a simple inspection, we can predict how well the die will function in our downstream production processes (Bottum, 1992; reversed).

3. We use several forms of inspection and several different metrics to evaluate die quality (Anderson et al., 2000).

4. When there is a problem with a die, we usually can determine its cause (reversed) (Parmigiani, 2007).

5. It is difficult to equitably measure one supplier's die vs. another supplier's (Anderson and Schmittlein, 1984).

Firm scope economies

1. By making our own dies, we could reduce our overall production costs of other products (Parmigiani, 2007).

2. We do better utilise our labour and equipment by making dies in addition to our other products (Parmigiani, 2007).

\section{Supplier scope economies}

1. By making dies for us, our suppliers can reduce their overall production costs since they can make better use of their labour and equipment (Parmigiani, 2007).

\section{Firm expertise}

1. Our manufacturing staff can easily produce dies (Parmigiani, 2007).

2. Making dies requires a deep expertise that our firm understands (Walker and Weber, 1984).

3. We have internally produced dies for years (Parmigiani, 2007).

4. The skills used to make dies are closely related to those that we use to make other similar products (Parmigiani, 2007).

\section{Supplier expertise}

1. The leading die suppliers have proprietary knowledge that gives them an advantage over other firms (Walker and Weber, 1984).

2. We rely on our suppliers to help us keep up with die technology (Stump and Heide, 1996).

3. There is very little difference between the process we would use to make dies and that used by a supplier (reversed) (Parmigiani, 2007).

4. As compared to suppliers, our internal production of dies would be higher in price (Anderson, 1985; reversed).

5. As compared to our suppliers, our internal production of dies would be lower in quality (Anderson, 1985; reversed).

\section{Theories}

1. We build up optimal contractual relationships with our suppliers based on incentives and other control mechanisms (Agency theories) (reversed).

2. We faced issues (problems) with suppliers and made rational and intelligent decisions to maximise our profit (Game) (reversed).

3. We outsource products and services when our internal resources and capabilities are weak (RBV).

4. We resolve make-or-buy decisions based on cost factors, whenever the potential for opportunism is low (TCE). 
5. We acquire innovation from suppliers by combining make-and-buy decisions (Innovation).

6. We adopt innovation from suppliers by outsourcing services and processes (Innovation) (reversed).

Journal of Industrial Engineering and Management, 2020 (www.jiem.org)

\section{(C) (1) $(9$}

Article's contents are provided on an Attribution-Non Commercial 4.0 Creative commons International License. Readers are allowed to copy, distribute and communicate article's contents, provided the author's and Journal of Industrial Engineering and Management's names are included. It must not be used for commercial purposes. To see the complete license contents, please visit https://creativecommons.org/licenses/by-nc/4.0/. 